Citation: G. Gilardi, A. Vasileiadou, A. Garibaldi, M. L. Gullino (2021) Biocontrol agents and resistance inducers reduce Phytophthora crown rot (Phytophthora capsicl) of sweet pepper in closed soilless culture. Phytopathologia Mediterranea 60(1): 149-163. doi: 10.36253/ phyto-11978

Accepted: January 5, 2021

Published: May 15, 2021

Copyright: $\odot 2021$ G. Gilardi, A. Vasileiadou, A. Garibaldi, M. L. Gullino. This is an open access, peer-reviewed article published by Firenze University Press (http://www.fupress.com/pm) and distributed under the terms of the Creative Commons Attribution License, which permits unrestricted use, distribution, and reproduction in any medium, provided the original author and source are credited.

Data Availability Statement: All relevant data are within the paper and its Supporting Information files.

Competing Interests: The Author(s) declare(s) no conflict of interest.

Editor: Epaminondas Paplomatas, Agricultural University of Athens, Greece.
Research Papers

\section{Biocontrol agents and resistance inducers reduce Phytophthora crown rot (Phytophthora capsici) of sweet pepper in closed soilless culture}

\author{
Giovanna GILARDi*, Athina VASILEIADOU, Angelo GARIBALDI, \\ Maria Lodovica GULLINO \\ Centre for Innovation in the Agro-Environmental Sector, AGROINNOVA, University of \\ Torino, Largo P. Braccini 2, 10095 Grugliasco (TO), Italy \\ *Corresponding author. E-mail: giovanna.gilardi@unito.it
}

Summary. Twelve trials, in closed soilless culture under controlled conditions, were carried out to evaluate the efficacy of resistance inducers (based on K-phosphite and $\mathrm{K}$-silicate used alone or in combination), and of experimental biocontrol agents (Trichoderma sp. TW2, a mixture of Pseudomonas FC 7B, FC 8B, and FC 9B, Fusarium solani FUS25, Pseudomonas sp. PB26), and a commercial formulation of Trichoderma gamsii + T. asperellum, against diseases caused by Phytophthora capsici of sweet pepper. The products were applied using three different protocols, and effects on incidence of Phytophthora crown, stem and root rots (\% dead plants), disease development (area under the disease progress curve; AUDPC), and plant fresh weights were evaluated. Potassium phosphite, applied directly at standard $\mathrm{P}_{2} \mathrm{O}_{5}: \mathrm{K}_{2} \mathrm{O}, 1.30+1.05$ $\mathrm{g} \mathrm{L}^{-1}$ ) and at half standard rates, onto growing media, or via nutrient solution, and before infestation of peat plant growing medium with P. capsici, provided the best disease management in a dose-dependent manner, with an $80 \%$ reduction of Phytophthora crown, stem and root rots for the standard dosage and for both types of application. These treatments also reduced proportions of dead plants by $47 \%$ from the standard rate and by $62 \%$ at the half standard rate, when applied via the nutrient solution or directly to the substrate. K-silicate alone partially reduced the percentage of dead plants, with efficacy of $20-23 \%$. No improvement in disease control was observed when $\mathrm{K}$-silicate was applied in combination with phosphite, while $\mathrm{K}$-silicate alone or combined with K-phosphite reduced disease development, compared to untreated controls. Biocontrol agents (BCAs), applied preventively, reduced Phytophthora crown, stem and root rots, with similar or better results than those from the commercial mixture of Trichoderma asperellum + T. gamsii. Among the tested BCAs, Fusarium solani FUS25 provided the most consistent disease reduction (60-65\%) and gave increased plant fresh weights. All the tested BCAs reduced disease development, with a similar trend for different disease pressures. The least AUDPC values, compared to the non-treated controls, were from Fusarium solani FUS25, followed by the tested Pseudomonas strains and Trichoderma sp. TW2. These results indicate the potential for potassium phosphite and biocontrol agents in management of Phytophthora crown, stem and root rots of pepper grown in soilless systems.

Keywords. Hydroponics, Phytophthora control, Capsicum annuum, salts, microorganisms. 


\section{INTRODUCTION}

Sweet pepper (Capsicum annuum) is a popular vegetable crop, which is greatly appreciated for its quality and taste for fresh consumption and for processing, and is increasingly grown in greenhouse environments. The commercial greenhouse production of this vegetable is extensive in European countries, including Spain $(12,420$ ha), Italy (2,370 ha), Poland (1,830 ha) and The Netherlands (1,320 ha) (2017 data; FAOSTAT 2019).

However, sweet pepper is frequently affected by pathogens, with soil-borne pathogens being important and causing severe crop losses (Owen-Going et al., 2003; Pernezny et al., 2003; Messelink et al., 2020). Among these Phytophthora capsici, which causes various diseases such as root, stem, and crown rots, resulted in economically important losses in most production areas (Matta and Garibaldi, 1981; Ristaino and Johnston, 1999; Hausbeck and Lamour, 2004; Granke et al., 2012). This pathogen is highly variable (Ristaino and Johnston, 1999; Matta and Garibaldi, 1981; Lee et al., 2001; Tamietti and Valentino, 2001; Foster and Hausbeck, 2010), and causes severe losses when grown either in soil or in soilless systems (Nielsen et al., 2006b), because it is difficult to manage (Messelink et al., 2020).

These diseases have been known in Italy since 1949 (Sibilia, 1952), and are still widespread, as a result of a lack of effective fumigants, no commercially acceptable resistant cultivars, and limited availability of resistant rootstocks which often only have partial resistance to the pathogen (Gilardi et al., 2014). Although several sweet pepper cultivars show full or partial resistance to P. capsici, stem blight, root rot and foliar blight of these cultivars are probably reduced by separate genetic systems, so that cultivars resistant to crown rot may not be resistant to foliar blight (Foster and Hausbeck, 2010). This complicates the use of genetic disease resistance in sweet pepper, increasing the need to improve marketable yield potential and good fruit quality (Barchenger et al., 2018; Acquadro et al., 2020). Development of pathogen resistance to fungicides, including the commonly used mefenoxam and metalaxyl (Bower and Coffey, 1985; Lamour and Hausbeck 2001; Parra and Ristaino, 2001; Tamietti and Valentino, 2001), and alternatives to phenylamides, such as cyazofamid, dimethomorph, flumorph and oxathiapoprolin (Bower and Coffey 1985; Kousik et al., 2008; Bi et al., 2014; Miao et al., 2016), has complicated management of these diseases.

Soilless cultivation is increasingly being adopted for many vegetable crops (Lee and Lee, 2015. Sambo et al., 2019), as this is a good option when crop rotation is not feasible and resistant cultivars are not available, and because of increasing limitations in the use of fumigants and fungicides (Garibaldi et al., 2014). Host species, plant growth substrate type and the target pathogen all play important roles in management of diseases in soilless cultivation (Zheng et al., 2000; van der Gaag and Wever, 2005; Khalil et al., 2009; Lee and Lee, 2015), and specific evaluations are required for new crops. The effects of soilless cultivation on sweet pepper have not been fully exploited, particularly in terms of effects on the reduction of soil-borne diseases, such as Phytophthora crown rot.

Apart from their intrinsic capability of reducing problems caused by soil-borne pathogens, soilless cultivation systems offer good opportunities for exploiting new disease management strategies, including the use of resistance inducers and biocontrol agents, where increasing limitations apply to use of traditional fungicides.

Several biocontrol agents (Rankin and Paulitz, 1994; Paulitz, 1997; Chatterton et al., 2004; Mercier and Manker, 2005; Calvo-Bado et al., 2006; Liu et al., 2007; Segarra et al., 2010; Köhl et al., 2011; Vallance et al., 2011; Gilardi et al., 2020), and other biocide products such as salts of phosphites and silicates, and nonionic surfactants (Stanghellini and Tomlinson, 1987; Cherif et al., 1994; Stanghellini and Rasmussen, 1994; Stanghellini et al., 1996; Stanghellini and Miller, 1997; Förster et al., 1998; Nielsen et al., 2006a; French-Monar et al., 2010; Song et al., 2016; Gilardi et al., 2020) have been tested against a number of soil-borne pathogens, including $P$. capsici, in soilless systems. However, most of the applications of these disease management tools require fine-tuning for type and application timing, particularly in soilless systems, before they can be practically implemented (Vallance et al., 2011).

The present study was carried out in an experimental closed soilless system, under controlled conditions, to evaluate the efficacy of host resistance inducers, based on K-phosphite and K-silicate, used alone or combined, and of experimental biocontrol agents, against $P$. capsici on sweet pepper. These treatments were compared with a commercial formulation of Trichoderma gamsii $+T$. asperellum. Different treatments and types and timing of application were tested, aiming to develop appropriate strategies for their application in practical soilless production systems.

\section{MATERIALS AND METHODS}

\section{Soilless growing system and experimental layout}

Twelve trials were carried out in a glasshouse at the AGROINNOVA Centre of Competence of the University 
of Torino, in Grugliasco, Torino, Italy, at temperatures ranging from 22 to $30^{\circ} \mathrm{C}$, using fully automated closed soilless system. This is a small-scale hydroponic system, with recirculating nutrient solution. Each hydroponic unit consisted of one channel (6 m long and $25 \mathrm{~cm}$ wide) connected to a storage tank ( $300 \mathrm{~L}$ capacity) filled with nutrient solution, which was automatically delivered to the plants using an electronic control unit (Idromat2, Calpeda S.p.a.). Nutrient solution (at $1.5-1.6 \mathrm{mS} \mathrm{cm}^{-1}$ ) was pumped by emitters (one per pot) at a flow rate of $6 \mathrm{~L} \mathrm{~h}^{-1}$ from the storage tank, and fed to plants through drip emitters, and was left to drain back into the storage tank by gravity. The plants were fertigated with 5:3:8 N:P:K fertilizer (nutrient solution containing 120 $\mathrm{mg} \mathrm{L}^{-1}$ total $\mathrm{N}, 30 \mathrm{mg} \mathrm{L}^{-1} \mathrm{P}$ and $150 \mathrm{mg} \mathrm{L}^{-1}$; conductivity $1.5-1.6 \mathrm{mS} \mathrm{cm}^{-1}$ ). Nutrient solutions contained: 11.24 $\mathrm{mM} \mathrm{NO}, 4.8 \mathrm{mM} \mathrm{NH}_{4}, 0.75 \mathrm{mM} \mathrm{KH}_{2} \mathrm{PO}_{4}, 0.75 \mathrm{mM}$ $\mathrm{K}_{2} \mathrm{SO}_{4}, 0.012 \mathrm{mM}$ Iron chelate EDTA, $2 \mathrm{mM} \mathrm{MgO}, 2$ $\mathrm{mM} \mathrm{SO}_{3}, 0.2 \mathrm{mM} \mathrm{B}, 0.001 \mathrm{mM}$ Mo, $0.15 \mathrm{mM} \mathrm{Zn}, 3.1$ $\mathrm{mM} \mathrm{CaO}, 0.05 \mathrm{mM} \mathrm{Cu}^{++}, 0.25 \mathrm{mM} \mathrm{Mn}$, and $12.2 \mathrm{mM} \mathrm{K}$. The $\mathrm{pH}$ and conductivity of the nutrient solutions were checked regularly by using a $\mathrm{pH}$ meter and a SevenGo DUO TM SG23 conductivity meter (Tettler). The irrigation programme (three to six times per day) was revised according to the environmental conditions, particularly temperature. Each experimental unit consisted of six pots replicated five times ( $\mathrm{n}=30$ pots). Two plants were planted in each pot, and six pots were each sub-replicate of 12 plants each. Five replicates were used per treatment (60 plants per treatment).

\section{Plant material, and tested products and protocols}

Fifteen-day-old plants of sweet pepper 'Corno di Toro' (Furia Sementi), which is susceptible to Phytophthora crown rot, were transplanted into $3 \mathrm{~L}$ capacity plastic pots filled with a growing medium containing: black peat soil (Brill Type 5: $15 \%$ of blond peat, $85 \%$ of black peat; $\mathrm{pH} 5.5-6.0,1,100 \mathrm{~g} \mathrm{~m}^{-3}$ of N:P:K and traces of molybdenum, Georgsdorf) in all the trials.

Each set of trials included one untreated and inoculated experimental control, and different treatments with salt products or biocontrol agents tested alone or in combinations, which were applied according to three different protocols (Table 1). These were:

Protocols I and II. The fertilizer-based phosphite (Alexine 95PS: $52 \% \mathrm{P}_{2} \mathrm{O}_{5}+42 \% \mathrm{~K}_{2} \mathrm{O}$, Massò), which is labelled as a phosphorus supplement for soilless application, and potassium silicate $\left(\mathrm{K}_{2} \mathrm{SiO}_{3}, 33.7\right.$ to $34.7 \%$, Andrea Gallo S.r.l.) were tested (Trials 1 to 6) in 2018 and 2019, to select the optimal rates and types of application for potassium phosphite and potassium silicate, used alone or in combinations. $\mathrm{K}_{2} \mathrm{SiO}_{3}$ at $200 \mathrm{mg} \mathrm{L}^{-1}$ and $\mathrm{K}$-phosphite were added directly to the nutrient solutions (NS) at the standard rate of $1.30 \mathrm{~g} \mathrm{~L}^{-1} \mathrm{P}_{2} \mathrm{O}_{5}+$ $1.05 \mathrm{~g} \mathrm{~L}^{-1} \mathrm{~K}_{2} \mathrm{O}$, or at half this rate $\left(0.65 \mathrm{P}_{2} \mathrm{O}_{5}+0.52 \mathrm{~g}\right.$ $\left.\mathrm{L}^{-1} \mathrm{~K}_{2} \mathrm{O}+0.525 \mathrm{~g} \mathrm{~L}^{-1}\right)$ in experimental Protocol I. The same products, alone or in combinations, were applied to each pot around the crown of the seedlings using $100 \mathrm{~mL}$ per pot of the suspension prepared according to Protocol II. The treatments were carried out three times every $7 \mathrm{~d}$ (Table 1 ).

Protocol III. The following BCAs, isolated from suppressive composts, were tested: Pseudomonas sp. PB26 (Pugliese et al., 2008), Fusarium solani FUS25 (Gullino and Pugliese, 2011), Trichoderma sp. TW2 (Cucu et al., 2020), and a 1:1:1 mixture of three Pseudomonas spp. strains: Pseudomonas sp. FC 7B (EU836174), Pseudomonas putida FC 8B (EU836171), and Pseudomonas sp. FC 9B (EU836172). These strains were previously isolated from a suppressive rockwool substrate in a soilless system (Clematis et al., 2009; Srinivasan et al., 2009) (Table 1). The bacterium strains were maintained at $4^{\circ} \mathrm{C}$ in Luria Bertani (LB) slants throughout the study. The fresh bacterium suspensions were each prepared by inoculating a loop-full of cells into $30 \mathrm{~mL}$ of $\mathrm{LB}$ medium in $100 \mathrm{ml}$ capacity Erlenmeyer flasks, and then incubating the suspension on a rotary shaker at $600 \mathrm{rpm}$. The cell suspension was centrifuged and resulting pellets were resuspended in sterile deionized water. The optical densities $\left(\mathrm{OD}_{600}\right)$ of cultures incubated for $48 \mathrm{~h}$ at $23^{\circ} \mathrm{C}$ were checked immediately before application, and was adjusted with sterile deionized water to $1 \times 10^{8}$ cells $\mathrm{mL}^{-1}$ before application. Trichoderma sp. TW2 was grown in a $1000 \mathrm{~mL}$ capacity flask containing $200 \mathrm{~mL}$ of potato dextrose broth (Sigma-Aldrich) and maintained under static conditions at $23^{\circ} \mathrm{C}$. After 13 to $15 \mathrm{~d}$, the produced conidia and mycelium were transferred to $200 \mathrm{~mL}$ of sterile distilled water and homogenized using a handheld rotary mixer. The conidium suspension obtained for the Trichoderma sp. TW2 isolate was standardized to $1 \times 10^{7} \mathrm{cfu} \mathrm{mL}^{-1}$.

The antagonist Fusarium solani FUS25 was propagated in $1000 \mathrm{~mL}$ capacity-flasks each containing $250 \mathrm{~mL}$ of potato dextrose broth maintained on a rotary shaker for 8 to $10 \mathrm{~d}$ at $160 \mathrm{rpm}$. The cultures were centrifuged at $8,000 \mathrm{~g}$ for $20 \mathrm{~min}$ at $4^{\circ} \mathrm{C}$. Conidia and mycelium pellets were each transferred into $200 \mathrm{~mL}$ of sterile distilled water and homogenized using a rotary mixer. The inoculum suspensions were adjusted with sterile deionized water to $1 \times 10^{7}$ conidia $\mathrm{mL}^{-1}$ before application.

Each BCA suspension was applied at a final concentration of $1 \times 10^{7} \mathrm{cfu} \mathrm{mL}^{-1}$ to each pot and around the base of 15 -d-old seedlings immediately after planting. 
The BCAs were applied to the growing medium five times at $7 \mathrm{~d}$ intervals using $100 \mathrm{~mL}$ per pot of the suspension, following experimental Protocol III (Table 1). The experimental BCAs were compared with a commercial formulation of Trichoderma asperellum + T. gamsii (10\% a.i.; 'Remedier', Isagro), applied at the label rate of $0.25 \mathrm{~g}$ per liter of peat substrate (Table 1).

\section{Phytophthora capsici strain and inoculation}

A highly virulent strain of Phytophthora capsici (coded PHC 6/16; AGROINNOVA culture collection), originally isolated from sweet pepper, was cultured on selective oomycete medium (Masago et al., 1977) at $20^{\circ} \mathrm{C}$ for 1 week. Zoospores were produced according to a modified protocol of that described by Kim et al., (1997). One mycelium/agar plug ( $5 \mathrm{~mm}$ in diam.), taken from an actively growing colony, was transferred to a $1000 \mathrm{~mL}$ capacity flask containing a wheat-hempseed medium (200 g wheat kernels, $100 \mathrm{~g}$ hempseeds, $320 \mathrm{~mL}$ water, sterilized at $121^{\circ} \mathrm{C}$ for $30 \mathrm{~min}$ ), and then incubated at $22^{\circ} \mathrm{C}$ in a growth chamber under continuous light for 7 $\mathrm{d}$, followed by $3 \mathrm{~d}$ at $15^{\circ} \mathrm{C}$ in darkness. Zoospore suspension was prepared by mixing $80 \mathrm{~g}$ of the oomycete biomass in $1 \mathrm{~L}$ of distilled water, mixing the suspension for
$10 \mathrm{~min}$, then removing the aqueous extract from solid sediment by filtering through two layers of cheesecloth and vigorously mixing it. Zoospores were released by chilling the liquid cultures at $4^{\circ} \mathrm{C}$ for $1 \mathrm{~h}$, followed by $1 \mathrm{~h}$ at room temperature $\left(25^{\circ} \mathrm{C}\right)$. The zoospore concentration was adjusted to $1 \times 10^{5}$ zoospores $\mathrm{mL}^{-1}$ using a haemocytometer. A $10 \mathrm{~mL}$ aliquot of the zoospore suspension was then pipetted onto the peat media around the base of each plant.

In trials 1 to 6 , the first treatment with salts was carried out $48 \mathrm{~h}$ before infestation of the peat substrate, while in trials 7 to 12 , the first treatment with BCAs was carried out $48-72 \mathrm{~h}$ before infestation of the peat substrate (Table 1).

\section{Disease assessments, and statistical analyses}

The sweet pepper plants were assessed starting from the first appearance of wilt caused by P. capsici root and crown infections. Disease incidence (DI) was evaluated at intervals of 3 to $7, \mathrm{~d}$ by counting and removing the dead plants with symptoms of Phytophthora root, crown and stem rot. At the final assessment, the remaining plants were removed by each pot and the total number of dead plants including those wilted, due to severe root

Table 1. Protocols adopted for different trials.

\begin{tabular}{|c|c|c|c|c|c|}
\hline $\begin{array}{l}\text { Experimental Protocol } \\
\text { (Trial number, year) }\end{array}$ & Artificial inoculation & $\begin{array}{l}\text { Tested treatment and } \\
\text { concentration }\end{array}$ & $\begin{array}{c}\text { Standard reference } \\
\text { (dosage) }\end{array}$ & $\begin{array}{l}\text { Application of the } \\
\text { treatments }\end{array}$ & $\begin{array}{l}\text { Number and interval } \\
\text { between treatments }\end{array}$ \\
\hline I $(1,2$ and $3 ; 2018)$ & $\begin{array}{l}48 \mathrm{~h} \text { after the first } \\
\text { treatment, with } 1 \times \\
10^{5} \text { zoospores } \mathrm{mL}^{-1}\end{array}$ & $\begin{array}{l}\text { Potassium phosphite } \\
\left(\mathrm{P}_{2} \mathrm{O}_{5}: \mathrm{K}_{2} \mathrm{O} 0.65+\right. \\
\left.0.525 \mathrm{~g} \mathrm{~L}^{-1}\right) \text { and } \\
\mathrm{K} \text {-silicate }(200 \\
\left.\text { mg L }{ }^{-1}\right) \text {, alone or } \\
\text { combined }\end{array}$ & $\begin{array}{l}\text { Potassium phosphite } \\
\left(\mathrm{P}_{2} \mathrm{O}_{5}: \mathrm{K}_{2} \mathrm{O} 1.30+\right. \\
\left.1.05 \mathrm{~g} \mathrm{~L}^{-1}\right)\end{array}$ & $\begin{array}{l}\text { In nutrient solution } \\
\text { (NS) }\end{array}$ & $\begin{array}{l}\text { Three applications, at } \\
7 \mathrm{~d} \text { intervals }\end{array}$ \\
\hline II $(4,5$ and $6 ; 2019)$ & $\begin{array}{l}48 \mathrm{~h} \text { after the first } \\
\text { treatment, with } 1 \times \\
10^{5} \text { zoospores } \mathrm{mL}^{-1}\end{array}$ & $\begin{array}{l}\text { Potassium phosphite } \\
\left(\mathrm{P}_{2} \mathrm{O}_{5} \mathrm{~K}_{2} \mathrm{O} 0.65+\right. \\
\left.0.525 \mathrm{~g} \mathrm{~L}^{-1}\right) \text { and } \\
\text { K-silicate }(200 \mathrm{mg} \\
\left.\mathrm{mL}^{-1}\right) \text {, alone or } \\
\text { combined }\end{array}$ & $\begin{array}{l}\text { Potassium phosphite } \\
\left(\mathrm{P}_{2} \mathrm{O}_{5} \mathrm{~K}_{2} \mathrm{O} 1.30+\right. \\
\left.1.05 \mathrm{~g} \mathrm{~L}^{-1}\right)\end{array}$ & To soil substrate & $\begin{array}{l}\text { Three applications, at } \\
7 \mathrm{~d} \text { intervals }\end{array}$ \\
\hline $\begin{array}{l}\text { III }(7,8,9,10,11 \text { and } \\
12 ; 2019-2020)\end{array}$ & $\begin{array}{l}48-72 \mathrm{~h} \text { after the first } \\
\text { treatment, with } 1 \times \\
10^{5} \text { zoospores } \mathrm{mL}^{-1}\end{array}$ & 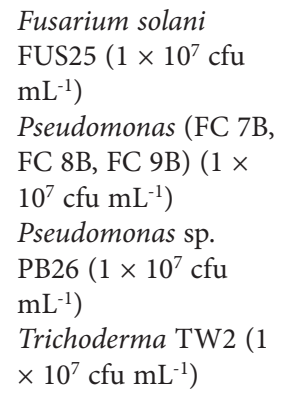 & $\begin{array}{l}\text { Trichoderma gamsii } \\
+ \text { T. asperellum }(0.25 \\
\left.\mathrm{g} \mathrm{L}^{-1}\right)\end{array}$ & To soil substrate & $\begin{array}{l}\text { Five applications, at } \\
7 \mathrm{~d} \text { intervals }\end{array}$ \\
\hline
\end{tabular}


infection by the pathogen, were counted. Final disease incidence (DI) was then calculated, expressed as percent, of dead and wilted plants over the total plants examined. Areas under the disease-progress curves (AUDPCs) were calculated using the formula of Shaner and Finney (1977), for a total number of observations per trial of three to five disease incidence assessments. The biomass of healthy plants (fresh weight from 1-2 cm above soil surface) in each experimental unit (six pots), was measured at the end of trials 7 to 12 in Protocol III.

The experimental units each consisted of a $3 \mathrm{~L}$ capacity pot with two plants (six pots), and sub-replicates contained 12 plants/treatment. Trials carried out using each of the three protocols were repeated at least three times (Tables 1 and 1S), and they were combined when the 'trial' factor was not statistically significant $(P>0.05)$.

Analysis of variance (ANOVA) with SPSS software (Version 26) was used to determine the effects of trial, treatments and their interactions, on disease incidence (DI) calculated at the end of each trial, AUDPC and fresh weight data. Prior to ANOVA, homogeneity of variances was evaluated and arcosin transformation of the percentage data was applied when necessary to normalize variances. When a statistically significant $\mathrm{F}$ test was obtained for treatments $(P \leq 0.05)$, the data were subjected to mean separation using Tukey's test at $P \leq 0.05$.

\section{RESULTS}

Efficacy of resistance inducers (dosage, type of application) against Phytophthora crown rot

First symptoms of Phytophthora root and crown rot and sometimes black lesion on stems started to be visible between 4 to $7 \mathrm{~d}$ after inoculation during the trials carried out using Protocols I and II. These symptoms then developed quickly (average air temperature ranging from 24 to $28^{\circ} \mathrm{C}$ ), with the final assessments carried out 27 to $33 \mathrm{~d}$ after planting (Protocol I), or 17 to $28 \mathrm{~d}$ after planting (Protocol II).

Both K-phosphite $(\mathrm{df}=2, \mathrm{~F}=261.324 ; P \leq 0.0001)$ and K-silicate, $(\mathrm{df}=1, \mathrm{~F}=5,220 ; P \leq 0.024)$, and K-phophite $+\mathrm{K}$-silicate $(\mathrm{df}=2, \mathrm{~F}=13.685 ; P \leq 0.0001)$ affected the percentage of dead plants (DI) and the development of Phytophthora crown rot (AUDPC) (K-phospite: $\mathrm{df}=2, \mathrm{~F}=161,784 ; P \leq 0.0001 . \mathrm{K}$-silicate: $\mathrm{df}$ $=1 ; \mathrm{F}=5,747 ; P \leq 0.018$. K-phosphote + K-silicate: $\mathrm{df}=$ $2 ; \mathrm{F}=13.823 ; P \leq 0.0001$ ) (Table 2). Neither the type of application of K-phosphite $(\mathrm{df}=2, \mathrm{~F}=0.431 ; P=0.263)$ or K-silicate ( $\mathrm{df}=1 ; \mathrm{F}=0.501 ; P=0.480$ ), nor the interaction of the K-phosphite $+\mathrm{K}$-silicate treatment with the type of application ( $\mathrm{df}=2 ; \mathrm{F}=1.089 ; P=0.339)$, affect-
Table 2. Analyses of variance for disease incidence (DI) as percentage of dead and wilted plants and areas under disease progress curve (AUDPCs) for pepper 'Corno di toro' plants inoculated with $P$. capsici and treated with salts treatments (K-phospite, K-silicate or $\mathrm{K}$-phospite + K-silicate), the type of application (in nutrient solution or to the soil substrate), and their interactions, calculated at the end of trails 1 to 6 , according to $F$ tests.

\begin{tabular}{lccc}
\hline \multirow{2}{*}{$\begin{array}{l}\text { Considered factors and their } \\
\text { interaction }\end{array}$} & $\mathrm{df}^{\mathrm{a}}$ & \multicolumn{2}{c}{ F values $^{\mathrm{b}}$} \\
\cline { 3 - 4 } & & $\mathrm{DI}$ & AUDPC \\
\hline $\begin{array}{l}\text { K-phosphite treatment } \\
\text { K-silicate treatment }\end{array}$ & 2 & $261.324^{* * *}$ & $161.784^{* * *}$ \\
$\begin{array}{l}\text { K-phosphite }+ \text { K-silicate combined } \\
\text { treatment }\end{array}$ & 1 & $461.312^{* * *}$ & $5.747^{* *}$ \\
$\begin{array}{l}\text { K-phosphite } \times \text { K-silicate interaction } \\
\text { K-phosphite } \times \text { type of application }\end{array}$ & 2 & 1 & $0.003^{* * *}$ \\
$\begin{array}{l}\text { K-silicate } \times \text { type of application } \\
\text { K-phosphite } \times \text { K-silicate } \times \text { type of } \\
\text { application }\end{array}$ & 1 & 0.501 & $0.685^{* * *}$ \\
\hline
\end{tabular}

${ }^{\text {a }}$ Degrees of freedom between groups.

${ }^{\mathrm{b}}$ Symbols ${ }^{*},{ }^{* *},{ }^{* * *}$ indicate significance at, respectively, $P \leq 0.05, P$ $\leq 0.001$ or $P \leq 0.0001$, according to $\mathrm{F}$ tests.

ed disease incidence. Similarly, these treatments did on affect crown rot development (K-phosphite: $\mathrm{df}=2, \mathrm{~F}=$ $0.679 ; P=0.359$. K-silicate: $\mathrm{df}=1, \mathrm{~F}=0.021 ; P=0.885$. K-phosphite + K-silicate: $\mathrm{df}=2, \mathrm{~F}=0.288 ; P=0.750$ ) (Table 2).

The DI and AUDPC data from each set of trials carried out according to Protocol I (Trials 1 to 3 ) or Protocol II (trials 4 to 6) were analyzed together for each experimental run (Tables 3 and 4), because statistically significant differences were not observed among trials $(P$ $>0.05$ ). The average incidence of Phytophthora root and crown rots was $46 \%$ in the untreated controls in trials 1 , 2 and 3 , and was greater $(\mathrm{DI}=93 \%)$ in trials 4,5 and 6 (Table 3).

The most efficacious control of the pathogen was observed from K-phosphite at the standard dosage $(80 \%$ efficacy) in all the experiments for both types of application (Table 3), while efficacy the half rate treatments also reduced percentage of dead plants (compared to the untreated controls) by $47 \%$, when applied via the nutrient solution, or by $62 \%$ when applied directly to the soil substrate.

$\mathrm{K}$-silicate alone reduced the percentage of dead plants with $20-23 \%$ efficacy. No improvement in disease control was observed when K-silicate was applied in combination with K-phosphite for either of the tested doses. Slightly less disease control was observed for K-phosphite, at the standard dosage, combined with K-silicate, when applied via nutrient solution (68\% efficacy) or to 
Table 3. Mean disease incidences from K-silicate or K-phosphite salt treatments, alone or in combinations, when applied against Phytophthora crown rot caused by Phytophthora capsici on soilless grown sweet pepper 'Corno di Toro' plants. Data are average percentages of wilted and dead plants (disease incidence, DI) at the end of trials 1, 2 and 3, where Protocol I was used (see text), and trials 4, 5 and 6, where Protocol II was used.

\begin{tabular}{|c|c|c|c|c|c|c|}
\hline \multirow{3}{*}{$\begin{array}{l}\text { Treatment (dosages: a.i.) }{ }^{\mathrm{a}} \\
\text { Untreated control }\end{array}$} & \multicolumn{6}{|c|}{ Mean Disease Incidence (DI) } \\
\hline & \multicolumn{3}{|c|}{$\begin{array}{l}\text { Treatments applied to the NS } \\
\text { (Protocol I) }\end{array}$} & \multicolumn{3}{|c|}{$\begin{array}{l}\text { Treatments applied to the substrate } \\
\text { (Protocol II) }\end{array}$} \\
\hline & $45.7 \pm 3.2$ & $\mathrm{~d}^{\mathrm{c}}$ & $\mathrm{E} \% \mathrm{~d}$ & $93.3 \pm 2.0$ & $\mathrm{~d}$ & $\mathrm{E} \%$ \\
\hline K-silicate $\left(200 \mathrm{mg} \mathrm{L}^{-1}\right)$ & $35.0 \pm 3.4$ & $\mathrm{~cd}$ & 23.4 & $73.3 \pm 5.0$ & c & 20.4 \\
\hline K-phosphite $\left(\mathrm{P}_{2} \mathrm{O}_{5}: \mathrm{K}_{2} \mathrm{O} 0.65,+0.525 \mathrm{~g} \mathrm{~L}^{-1}\right)$ & $24.4 \pm 3.4$ & $\mathrm{bc}$ & 46.5 & $35.6 \pm 3.2$ & $\mathrm{~b}$ & 61.1 \\
\hline K-phosphite $\left(\mathrm{P}_{2} \mathrm{O}_{5}: \mathrm{K}_{2} \mathrm{O}, 0.65+0.525 \mathrm{~g} \mathrm{~L}^{-1}\right)+\mathrm{K}$-silicate $\left(200 \mathrm{mg} \mathrm{L}^{-1}\right)$ & $21.7 \pm 2.5$ & $\mathrm{~b}$ & 52.6 & $34.4 \pm 1.8$ & $\mathrm{~b}$ & 63.1 \\
\hline K-phosphite $\left(\mathrm{P}_{2} \mathrm{O}_{5}: \mathrm{K}_{2} \mathrm{O}, 1.30+1.05 \mathrm{~g} \mathrm{~L}^{-1}\right)$ & $8.9 \pm 2.1$ & a & 80.5 & $18.3 \pm 2.3$ & a & 80.4 \\
\hline K-phosphite $\left(\mathrm{P}_{2} \mathrm{O}_{5}: \mathrm{K}_{2} \mathrm{O}, 1.30+1.05 \mathrm{~g} \mathrm{~L}^{-1}\right)+\mathrm{K}$-silicate $\left(200 \mathrm{mg} \mathrm{L}^{-1}\right)$ & $14.4 \pm 1.3$ & $\mathrm{ab}$ & 68.4 & $24.4 \pm 2.6$ & $\mathrm{ab}$ & 73.8 \\
\hline Trial $^{\mathrm{b}}$ & \multicolumn{3}{|c|}{$\mathrm{df}=2 ; \mathrm{F}=2.888 ; P=0.057$} & \multicolumn{3}{|c|}{$\mathrm{df}=2 ; \mathrm{F}=0.9555 ; P=0.389$} \\
\hline K-phosphite & \multicolumn{3}{|c|}{$\mathrm{df}=1 ; \mathrm{F}=50.910 ; P<0.0001$} & \multicolumn{3}{|c|}{$\mathrm{df}=1 ; \mathrm{F}=186.005 ; P<0.0001$} \\
\hline K-silicate & \multicolumn{3}{|c|}{$\mathrm{df}=1 ; \mathrm{F}=7.704 ; P=0.007$} & \multicolumn{3}{|c|}{$\mathrm{df}=1 ; \mathrm{F}=9.469 ; P=0.003$} \\
\hline K-phosphite + K-silicate combined treatment & \multicolumn{3}{|c|}{$\mathrm{df}=1 ; \mathrm{F}=6,429 ; P=0.017$} & \multicolumn{3}{|c|}{$\mathrm{df}=1 ; \mathrm{F}=9,870 ; P=0.004$} \\
\hline K-phosphite $\times$ K-silicate interaction & \multicolumn{3}{|c|}{$\mathrm{df}=1 ; \mathrm{F}=8.432 ; P=0.005$} & \multicolumn{3}{|c|}{$\mathrm{df}=1 ; \mathrm{F}=2.918 ; P=0.05$} \\
\hline Treatments & \multicolumn{3}{|c|}{$\mathrm{df}=5 ; \mathrm{F}=24.040 ; P<0.0001$} & \multicolumn{3}{|c|}{$\mathrm{df}=5 ; \mathrm{F}=97.006 ; P<0.0001$} \\
\hline
\end{tabular}

${ }^{a} \mathrm{~K}_{2} \mathrm{SiO}_{3}$ at $200 \mathrm{mg} \mathrm{L}^{-1}$ and $\mathrm{K}$-phosphite (standard dosage of $\mathrm{P}_{2} \mathrm{O}_{5}: \mathrm{K}_{2} \mathrm{O}, 1.30+1.05 \mathrm{~g} \mathrm{~L}^{-1}$ or half dosage of $\mathrm{P}_{2} \mathrm{O}_{5}: \mathrm{K}_{2} \mathrm{O}, 0.65+0.525 \mathrm{~g} \mathrm{~L}-1$ ) or their combinations, were added directly to the nutrient solution NS (Protocol I), or to the soil substrate (Protocol II) in each pot using 100 $\mathrm{mL} /$ pot of suspension. The treatments were carried out three times, at $7 \mathrm{~d}$ intervals.

${ }^{b}$ Values from trials 1,2 and 3 or trials 4,5 or 6 , each with five replicates per treatment, were combined when statistically significant differences were not observed (Trial $P>0.05$ ). Significant according to the $\mathrm{F}$ tests and degrees of freedom (df) used in its calculation. Each mean is associated with its standard error $( \pm \mathrm{SE})$.

${ }^{c}$ Means in the same column, followed by the same letter, do not differ according to Tukey's Test $(P \leq 0.05)$. Each mean is associated with its standard error $( \pm \mathrm{SE})$.

${ }^{\mathrm{d}} \mathrm{E} \%$ : percentage reduction of disease incidence of wilted and dead plants, compared to the untreated controls, at the end of trials 1,2 or 3 , corresponding to, respectively, 30, 25 or $24 \mathrm{~d}$ after inoculation (Protocol I), and at the end of trials 4, 5 or 6 , corresponding to, respectively, 35, 21 or $17 \mathrm{~d}$ after inoculation (Protocol II).

the substrate (74\% efficacy) (Table 3). Similar effects were observed for K-phosphite, at a reduced dosage, combined with K-silicate, when applied via nutrient solution (53\% efficacy) or to the substrate (63\% efficacy) (Table 3).

For AUDPC values, K-silicate reduced disease development, compared to the untreated control, for both types of application. K-phosphite, at both tested dosages, applied alone or combined with K-silicate, affected AUDPC compared to the untreated control, and differences among these treatments (Table 4).

$\mathrm{K}$-phosphite and K-silicate either alone or combined, applied via nutrient solution or when distributed to the growing medium, did not reduce the development of sweet pepper plants (data not shown).

\section{Effects of biocontrol agents}

First symptoms of Phytophthora root and crown rots started to be visible at 5 to $13 \mathrm{~d}$ after inoculations with $P$. capsici carried out $48-72 \mathrm{~h}$ after planting during the tri- als carried out using Protocol III. These symptoms rapidly under the experimental conditions used (average air temperature 24 to $28^{\circ} \mathrm{C}$ ), with the final assessment carried out between 34 to $37 \mathrm{~d}$ after planting trials 7-9, and 23 to $26 \mathrm{~d}$ in trials 10-12 carried out with Protocol III.

The data from trials 7,8 and $9(\mathrm{DI}, \mathrm{df}=2, \mathrm{~F}=0.369$, $P=0.545 ;$ AUDPC, $\mathrm{df}=2, \mathrm{~F}=0.073, P=0.930)$, and from trials 10,11 and $12(\mathrm{DI}, \mathrm{df}=2, \mathrm{~F}=2.252, P=$ 0.111; AUDPC, $\mathrm{df}=2, \mathrm{~F}=0.781, P=0.461$ ), were combined when there was heterogeneity between the trial runs (Tables 5 and 6). Inoculation with the pathogen led to high disease incidence in the untreated controls $(78 \%$ in trials 7, 8 and 9 and $63 \%$ in trials 10,11 and 12), permitting evaluation of the different BCAs under study (Table 5). All the BCAs reduced DI in the trials 7, 8 and $9(\mathrm{df}=5, \mathrm{~F}=18.021, P<0.0001)$ and in trials 10,11 and $12(\mathrm{df}=5, \mathrm{~F}=15.538, P<0.0001)$, compared to the untreated controls. The experimental biocontrol agents generally gave more disease control than the commercial formulation of Trichoderma asperellum + T. gamsii 
Table 4. Mean areas under disease progress (AUDPCs) after treatments with K-silicate and K-phosphite salts, alone or in combinations, applied against Phytophthora crown rot caused by Phytophthora capsici to soilless grown plants of sweet pepper 'Corno di Toro'. These data were obtained at the end of trials 1, 2 and 3, using Protocol I, and trials 4, 5 and 6 using Protocol II (see text).

\begin{tabular}{|c|c|c|c|c|}
\hline \multirow{3}{*}{$\begin{array}{l}{\text { Treatment (Dosage a.i. })^{\mathrm{a}}} \\
\text { Untreated control }\end{array}$} & \multicolumn{4}{|c|}{$\mathrm{AUDPC}^{b}$} \\
\hline & \multicolumn{2}{|c|}{$\begin{array}{l}\text { Treatment applied to the NS } \\
\text { (Protocol I) }\end{array}$} & \multicolumn{2}{|c|}{$\begin{array}{l}\text { Treatment applied to the substrate } \\
\text { (Protocol II) }\end{array}$} \\
\hline & $846.4 \pm 76.01$ & $\mathrm{c}^{\mathrm{d}}$ & $1,376.9 \pm 60.8$ & $\mathrm{c}$ \\
\hline K-silicate $\left(200 \mathrm{mg} \mathrm{L}^{-1}\right)$ & $533.6 \pm 47.7$ & $\mathrm{~b}$ & $1,045.0 \pm 105.9$ & $\mathrm{~b}$ \\
\hline K-phosphite $\left(\mathrm{P}_{2} \mathrm{O}_{5}: \mathrm{K}_{2} \mathrm{O} 0.65+0.525 \mathrm{~g} \mathrm{~L}^{-1}\right)$ & $413.3 \pm 59.7$ & $\mathrm{ab}$ & $396.9 \pm 46.2$ & a \\
\hline $\begin{array}{l}\text { K-phosphite }\left(\mathrm{P}_{2} \mathrm{O}_{5}: \mathrm{K}_{2} \mathrm{O} 0.65+0.525 \mathrm{~g} \mathrm{~L}^{-1}\right)+\mathrm{K} \text {-silicate }(200 \mathrm{mg} \\
\left.\mathrm{L}^{-1}\right)\end{array}$ & $452.8 \pm 54.3$ & $\mathrm{ab}$ & $404.4 \pm 33.4$ & a \\
\hline K-phosphite $\left(\mathrm{P}_{2} \mathrm{O}_{5}: \mathrm{K}_{2} \mathrm{O} 1.30+1.05 \mathrm{~g} \mathrm{~L}^{-1}\right)$ & $236.9 \pm 45.2$ & a & $219.2 \pm 35.7$ & a \\
\hline K-phosphite $\left(\mathrm{P}_{2} \mathrm{O}_{5}: \mathrm{K}_{2} \mathrm{O} 1.30+1.05 \mathrm{~g} \mathrm{~L}^{-1}\right)+\mathrm{K}$-silicate $\left(200 \mathrm{mg} \mathrm{L}^{-1}\right)$ & $259.4 \pm 31.9$ & a & $321.4 \pm 43.2$ & a \\
\hline Trial $^{\mathrm{d}}$ & \multicolumn{2}{|c|}{$\mathrm{df}=2 ; \mathrm{F}=2.442 ; P=0.093$} & \multicolumn{2}{|c|}{$\mathrm{df}=2 ; \mathrm{F}=0.388 P=0.244$} \\
\hline K-phosphite & \multicolumn{2}{|c|}{$\mathrm{df}=1 ; \mathrm{F}=28.861 ; P<0.0001$} & \multicolumn{2}{|c|}{$\mathrm{df}=1 ; \mathrm{F}=26.036 ; P<0.0001$} \\
\hline K-silicate & \multicolumn{2}{|c|}{$\mathrm{df}=1 ; \mathrm{F}=9.202 ; P=0.003$} & \multicolumn{2}{|c|}{$\mathrm{df}=1 ; \mathrm{F}=4.951 ; P=0.029$} \\
\hline K-phosphite $+\mathrm{K}$-silicate combined treatment & \multicolumn{2}{|c|}{$\mathrm{df}=1 ; \mathrm{F}=9,423 ; P=0.005$} & \multicolumn{2}{|c|}{$\mathrm{df}=1 ; \mathrm{F}=5,311 ; P=0.014$} \\
\hline K-phosphite $\times$ K-silicate interaction & \multicolumn{2}{|c|}{$\mathrm{df}=1 ; \mathrm{F}=9.485 ; P=0.003$} & \multicolumn{2}{|c|}{$\mathrm{df}=1 ; \mathrm{F}=12.976 ; P=0.001$} \\
\hline Treatment & \multicolumn{2}{|c|}{$\mathrm{df}=5 ; \mathrm{F}=16.800 ; P<0.0001$} & \multicolumn{2}{|c|}{$\mathrm{df}=5 ; \mathrm{F}=61.923 ; P<0.0001$} \\
\hline
\end{tabular}

${ }^{\mathrm{a}} \mathrm{K}_{2} \mathrm{SiO}_{3}$ at $200 \mathrm{mg} \mathrm{L}-1$ and K-phosphite (standard dosage of $\mathrm{P}_{2} \mathrm{O}_{5}: \mathrm{K}_{2} \mathrm{O} 1.30+1.05 \mathrm{~g} \mathrm{~L}^{-1}$ or half dosage of $\mathrm{P}_{2} \mathrm{O}_{5}: \mathrm{K}_{2} \mathrm{O} 0.65+0.525 \mathrm{~g} \mathrm{~L}^{-1}$ ) or their combinations, added directly to the nutrient solution NS (Protocol I), or to the substrate in each pot using $100 \mathrm{~mL}$ per pot of the suspension prepared (Protocol II). The treatments were carried out three times every 7 days.

${ }^{\mathrm{b}}$ AUDPC values were calculated for three to four assessments at 6-7 d intervals during trials 1, 2 and 3 (Protocol I), and four or five assessments at 3-6 d intervals during trials 4, 5 and 6 (Protocol II).

${ }^{c}$ Values from trials 1,2 and 3 or trials 4,5 and 6, each with five replicates per treatment, are combined when statistically significant differences (trial $P>0.05$; F tests) were not observed.

${ }^{\mathrm{d}}$ Means in each column followed by the same letter are not different $(P \leq 0.05$; Tukey's Test). Each mean is associated with its standard error $( \pm \mathrm{SE})$.

Table 5. Mean Phytophthora crown rot incidences after applications of experimental BCA treatments, applied according to Protocol III, on for soilless grown sweet pepper 'Corno di Toro'. The data are average disease incidence (DI) at the end of trials 7, 8 and 9 and 10, 11 and 12 .

\begin{tabular}{|c|c|c|c|c|c|c|}
\hline \multirow{3}{*}{$\begin{array}{l}\text { Treatment }^{\mathrm{a}} \\
\text { Untreated control }\end{array}$} & \multicolumn{6}{|c|}{ Disease incidence (DI) } \\
\hline & \multicolumn{3}{|c|}{ Trials 7, 8, and 9} & \multicolumn{3}{|c|}{ Trials 10,11 and 12} \\
\hline & $77.8 \pm 3.2$ & $\mathrm{~d}^{\mathrm{c}}$ & $\% \mathrm{E}^{\mathrm{d}}$ & $62.5 \pm 4.2$ & $\mathrm{c}$ & $\% \mathrm{E}$ \\
\hline Fusarium solani FUS 25 & $30.6 \pm 4.0$ & a & 60.7 & $22.2 \pm 3.3$ & $\mathrm{a}$ & 64.4 \\
\hline Pseudomonas sp. FC 7, FC 8, FC 9 & $42.8 \pm 4.1$ & $\mathrm{ab}$ & 45.0 & $30.4 \pm 3.0$ & $\mathrm{ab}$ & 51.4 \\
\hline Pseudomonas sp. PB 26 & $40.6 \pm 3.5$ & $\mathrm{ab}$ & 47.9 & $34.4 \pm 3.2$ & $\mathrm{ab}$ & 44.9 \\
\hline Trichoderma sp. TW 2 & $46.7 \pm 4.7$ & $\mathrm{~b}$ & 40.0 & $36.9 \pm 3.0$ & $\mathrm{~b}$ & 40.9 \\
\hline Trichoderma asperellum + T. gamsii & $61.1 \pm 4.2$ & c & 21.4 & $36.4 \pm 3.8$ & $\mathrm{~b}$ & 41.8 \\
\hline Trial $^{\mathrm{b}}$ & \multicolumn{3}{|c|}{$\mathrm{df}=2 ; \mathrm{F}=0.369 ; P=0.545$} & \multicolumn{3}{|c|}{$\mathrm{df}=2 ; \mathrm{F}=0.781 ; P=0.461$} \\
\hline Treatment & \multicolumn{3}{|c|}{$\mathrm{df}=5 ; \mathrm{F}=18.021 ; P<0.0001$} & \multicolumn{3}{|c|}{$\mathrm{df}=5 ; \mathrm{F}=15.538 ; P<0.0001$} \\
\hline
\end{tabular}

${ }^{a}$ The BCA suspensions were applied (at $1 \times 10^{7} \mathrm{cfu} \mathrm{mL}^{-1}$ ) to each pot and around the base of $15 \mathrm{~d}$-old seedlings after planting, six times at 5 $\mathrm{d}$ intervals using $100 \mathrm{~mL}$ per pot of the suspension. The experimental BCAs were compared with a commercial formulation of Trichoderma asperellum + T. gamsii ( $10 \%$ a.i., 'Remedier', Isagro), applied at the label rate of $0.25 \mathrm{~g} \mathrm{~L}^{-1}$ of peat substrate.

${ }^{\mathrm{b}}$ Values from trials 7,8 and 9 or trials 10,11 and 12, each with five replicates per treatment, are combined when statistically significant differences $(P>0.05$; F tests) were not observed.

${ }^{c}$ Means in each column followed by the same letter are not different $(P \leq 0.05$; Tukey's Test). Each mean is associated with its standard error $( \pm \mathrm{SE})$.

${ }^{\mathrm{d}} \mathrm{E} \%$ : percent disease incidence reduction, calculated as dead and wilted plants, compared to the untreated controls, at the end of the trials corresponding to 31,31 or $34 \mathrm{~d}$ after inoculation for, respectively, trials 7, 8 and 9, and 23, 21 or 22 days after inoculation for, respectively, trials 10,11 and 12 . 
Table 6. Mean areas under disease progress curves after applications of different experimental BCA treatments, applied according to Protocol III, for Phytophthora crown rot caused by P. capsici on soilless grown sweet peppers 'Corno di Toro'. The data are expressed as average area under disease progress (AUDPC) at the end of trials 7-9 and 10-12.

\begin{tabular}{|c|c|c|c|c|}
\hline \multirow{3}{*}{$\begin{array}{l}\text { Treatment }^{\mathrm{a}} \\
\text { Untreated control }\end{array}$} & \multicolumn{4}{|c|}{$\mathrm{AUDPC}^{\mathrm{b}}$} \\
\hline & \multicolumn{2}{|c|}{ Trials 7,8 and 9} & \multicolumn{2}{|c|}{ Trials 10,11 and 12} \\
\hline & $1,814.4 \pm 75.7$ & $\mathrm{~d}^{\mathrm{d}}$ & $1,457.2 \pm 62.9$ & $\mathrm{c}$ \\
\hline Fusarium solani FUS 25 & $584.7 \pm 72.2$ & a & $442.6 \pm 57.8$ & $\mathrm{a}$ \\
\hline Pseudomonas sp. FC 7, FC 8, FC 9 & $852.8 \pm 103.7$ & $a-c$ & $574.6 \pm 55.5$ & $a b$ \\
\hline Pseudomonas sp. PB 26 & $806.1 \pm 76.3$ & $\mathrm{ab}$ & $673.3 \pm 72.1$ & $\mathrm{ab}$ \\
\hline Trichoderma sp. TW 2 & $947.2 \pm 80.7$ & $\mathrm{bc}$ & $727.5 \pm 57.5$ & $\mathrm{~b}$ \\
\hline Trichoderma asperellum + T. gamsii & $1,170.0 \pm 77.2$ & c & $660.3 \pm 61.1$ & $a b$ \\
\hline
\end{tabular}

\begin{tabular}{lll}
\hline Trial $^{\mathrm{c}}$ & $\mathrm{df}=2 ; \mathrm{F}=0.073 ; P=0.930$ & $\mathrm{df}=2 ; \mathrm{F}=2.252 ; P=0.111$ \\
Treatment & $\mathrm{df}=5 ; \mathrm{F}=27.655 ; P<0.0001$ & $\mathrm{df}=5 ; \mathrm{F}=33.733 ; P<0.0001$
\end{tabular}

a The BCA suspensions $\left(1 \times 10^{7} \mathrm{cfu} \mathrm{mL}^{-1}\right)$ were applied five times after planting at $7 \mathrm{~d}$ intervals to individual pots around the base of 15 d-old seedlings, using $100 \mathrm{ml}$ of suspension per pot. The experimental BCAs were compared with a commercial formulation of Trichoderma asperellum + T. gamsii (10\% a.i.; 'Remedier', Isagro), applied at the label rate of $0.25 \mathrm{~g} \mathrm{~L}^{-1}$ of peat substrate.

${ }^{\mathrm{b}}$ AUDPC values were calculated considering four to five assessments at 4 to $9 \mathrm{~d}$ intervals during trials 7,8 and 9 , and four assessments at 4 to $8 \mathrm{~d}$ intervals during trials 10,11 and 12 .

${ }^{c}$ Values from trials 7,8 and 9 or trials 10,11 and 12, each with five replicates per treatment, are combined when statistically significant differences $(P>0.05$; F tests with and degrees of freedom $(\mathrm{df})$ indicated.

${ }^{\mathrm{d}}$ Means each column accompanied by the same letter are not different $(P \leq 0.05$; Tukey's Test). Each mean is accompanied by its standard error $( \pm \mathrm{SE})$.

(22 to $42 \%$ efficacy). The greatest and most consistent $P$. capsici control was from Fusarium solani FUS25, which reduced proportions of dead plants by 61 to $65 \%$. Both of the tested experimental Pseudomonas treatments (PB 26 and the mixture of FC 7B, FC 8B and FC 9B) showed

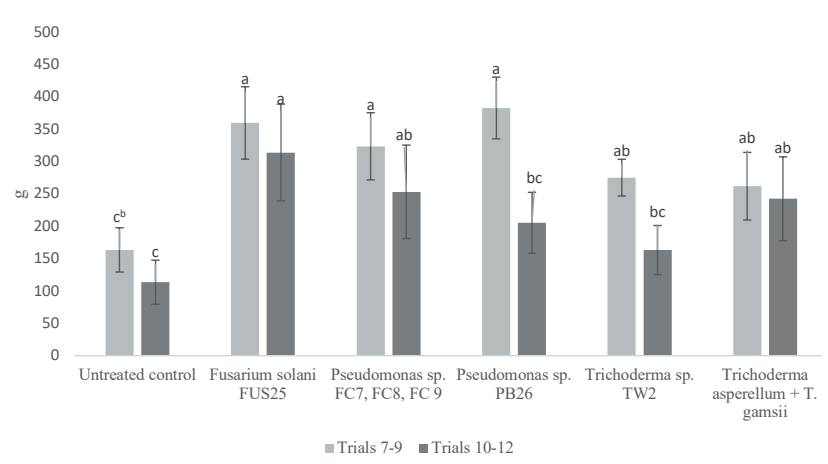

Figure 1. Mean fresh weight biomass $(\mathrm{g})^{\mathrm{a}}$ of healthy sweet peppers 'Corno di Toro' plants treated according to Protocol III at the end of trials 7,8 and 9 (31 to $34 \mathrm{~d}$ after inoculation), and trials 10,11 and 12 (21 to $23 \mathrm{~d}$ after inoculation). ${ }^{\text {a }}$ Mean fresh weight of plants per treatment from trials 7,8 and $9(\mathrm{df}=5 ; \mathrm{F}=30.446 ; P<0.0001)$ or trials 10,11 and $12(\mathrm{df}=5 ; \mathrm{F}=34.384 ; P<0.0001)$, each with five replicates per treatment, are combined because significant differences were not observed for trials 7,8 and $9(\mathrm{df}=2 ; \mathrm{F}=2.684$ $P=0.055)$ or trials 10,11 and $12(\mathrm{df}=2 ; \mathrm{F}=1.701 P=0.190)$, as indicated by $\mathrm{F}$ tests. ${ }^{\mathrm{b}}$ Means accompanied by the same letter do not differ ( $P \leq 0.05$; Tukey's Test). Each mean is accompanied by associated with its standard error $( \pm S E)$. similar disease control trends, with 45 to $51 \%$ disease reduction, compared to the untreated controls. Trichoderma sp. TW2, applied to the growing media every $7 \mathrm{~d}$, provided a consistent disease reduction of $40-41 \%$.

Disease reductions were observed for all the tested BCAs, and a similar trend was observed for the different disease amounts in trials 7,8 and $9(\mathrm{df}=5, \mathrm{~F}=27.655$, $P<0.0001)$ and trials 10,11 and $12(\mathrm{df}=5, \mathrm{~F}=33.733$, $P<0.0001)$. The least AUDPC values, compared to the non-treated controls, were from Fusarium solani FUS25, followed by the tested Pseudomonas strains and Trichoderma TW2 (Table 6).

Applications of the BCAs to the growing media generally increased fresh plant biomass at the end of both sets of trials, compared to the untreated controls, although inconsistent results were observed for Pseudomonas PB26 and Trichoderma TW2 (Figure 1).

\section{DISCUSSION}

Phytophthora capsici is a broad host range pathogen (Granke et al., 2012), important in most sweet pepper growing areas. There are few chemical options for management of the diseases caused by this pathogen, due to the lack of effective soil fumigants, its resistance to some effective fungicides (Bower and Coffey, 1985; Hwang et al., 1996; Lamour and Hausbeck, 2001; Parra and 
Ristaino, 2001; Tamietti and Valentino, 2001; Kousik et al., 2008; Miao et al., 2016; Barchenger et al., 2018; Hunter et al., 2018), and the complexity for host breeding to select cultivars resistant to local pathogen isolates (Acquadro et al., 2020).

Soilless crop cultivation is expanding throughout the world, but by itself this approach cannot solve the problems of managing soil-borne pathogens (Jenkins and Averre, 1983), since many of them, including P. capsici, may be introduced through infected planting material (Granke et al., 2012) or irrigation water (Ristaino et al., 1993; Hong and Moorman, 2005; Gevens et al., 2007). Growth and spread of zoosporic pathogens are particularly severe problems in soilless systems (Stanghellini and Rasmussen, 1994). Management strategies that minimize inoculum dispersal have, therefore, considerable potential for disease reduction. Increased understanding of the impacts of crop management measures in soilless systems is needed for the sweet pepper-P. capsici pathosystem.

The present study examined the efficacy of resistance inducers, based on K-phosphite and K-silicate, used alone or in combinations, and of experimental biocontrol agents under conditions of high disease pressure, in a closed soilless system. K-silicate only partially reduced the incidence of $P$. capsici (20-23\% efficacy) and its development, also when combined with K-phosphite, at the tested standard or reduced dosages. However, phosphite combinations could possibly reduce the risks of selection of Phytophthora isolates resistant to phosphite (Hunter et al., 2018), and address control of more than one pathogen in integrated pest management. Addition of 75 or $100 \mathrm{mg} \mathrm{L}^{-1}$ of silicon to the hydroponic nutrient solution reduced the severity of anthracnose caused by Colletotrichum capsici or C. gloeosporioides in Capsicum annuum (Jayawardana et al., 2015).

The mode of action of silicates and their functioning in several pathosystems are not yet fully understood. French-Monar et al., (2010) reported that bell pepper plants treated with calcium silicate had reduced root lesions and crown and stem necrosis caused by P. capsici, although at lower levels of reduction than found in other hosts. Together with possible formation of physical barriers to pathogens, from silicon accumulation in plants with differences depending on species, this element can influence plant defense responses and interact with key components of plant stress signalling systems, thus leading to induced resistance to pathogens (Liang et al., 2006; Wang et al., 2017).

Of the products tested in the present study, potassium phosphite provided the best control of P. capsici, when applied to pepper plants by adding soluble forms to nutrient solution of the closed hydroponic system, and when added to the growing medium. No effects on pepper development were detected after addition of this compound. However, the possible phytotoxic effects of phosphite, applied in soilless systems via a nutrient solution, should be considered. These compounds may precipitate and accumulate, as has been described for several fertilizers (Sambo et al., 2019). For example, tomato and pepper plants treated with either commercial or technical formulations of phosphite in a soilless system exhibited reduced growth (Forster et al., 1998).

The results obtained in the present study are similar to those of Förster et al. (1998), who observed reduced symptoms caused by $P$. capsici on tomato and pepper plants grown in a greenhouse hydroponic system treated with phosphite. Several factors are associated with the inhibition of pathogen growth as a result of phosphite treatments. These include phosphite concentration, the nature of the salts, the acidification of the plant growth medium and the pathogen life cycle (Guest and Bompeix, 1990; Smillie et al., 1989; Khalil et al., 2009; Khalil and Alsanius, 2011; Sambo et al., 2019). The results obtained in the present study show that the concentration of applied K-phosphite affected control of Phytophthora root and crown rot of sweet pepper, with greatest control provided by the standard dosages here tested.

Phosphite may act directly on pathogens, by inhibiting their growth (Fenn and Coffey, 1984, Smillie et al., 1989; Grant et al., 1990; Smillie et al., 1989), and possibly by priming the host defense in several pathosystems during pre-infection or post-inoculation stages of the pathogens. Liu et al. (2016) reported that phosphite, at $>5 \mu \mathrm{g} \mathrm{mL}^{-1}$, had a direct effect on mycelium growth and zoospore production in the sweet pepper-P. capsici pathosystem. Moreover, this compound increased transcription of antioxidant enzyme genes, and those involved in ethylene and abscisic acid biosynthesis, which mediated control of the pathogen at a higher phosphite concentration $\left(\mathrm{g} \mathrm{L}^{-1}\right)$ (Liu et al., 2016).

Phosphites are receiving a growing interest in horticulture (Gomez-Merino and Trejo-Téllez, 2015). Their application to soilless cultivation should be tested on different host-pathogen combinations, because some host plants are more responsive to phosphite than others (Guest and Bompeix, 1990; Shearer and Crane, 2012). Potassium phosphite reduced the Phytophthora crown rot of soilless grown zucchini grown by $62-94 \%$, when applied directly to growing media, or via a nutrient solution, when the pathogen was inoculated 5-7 d before planting (Gilardi et al., 2020). Phosphites are particularly active against oomycetes and have long been used for management of Phytophthora diseases in several 
crops (Fenn and Coffey 1984; Smillie et al., 1989; Guest and Bompeix, 1990; Förster et al., 1998, Dobrowolski et al., 2008), and in specific situations, based on greenhouse and field studies of soil-borne pathogens in several pathosystems. These include tomato/Phytophthora nicotianae (Gilardi et al., 2014); zucchini/P. capsici (Gilardi et al., 2015); lettuce/Fusarium oxysporum f. sp. lactucae; rocket/Fusarium oxysporum f. sp. raphani (Gilardi et al., 2016); potato/Rhizoctonia solani (Lobato et al., 2010), and common bean/Sclerotinia sclerotiorum (Fagundes-Nacarath et al., 2008).

Biocontrol agents may be worthwhile for disease management in soilless production systems (Paulitz, 1997; Postma, 2009; Vallance et al., 2011; Lee and Lee, 2015). In the past 20 years, several studies have demonstrated reduced disease and practical implementation (Lamichhane et al., 2017; Villeneuve, 2017; Barratt et al., 2018; Raymaekers et al., 2020). In the present study, the Pseudomonas putida isolate mixture (FC 7B, FC 8B, FC 9B), Pseudomonas sp. PB26, F. solani FUS25 and Trichoderma sp. TW2, introduced into the soilless system $48-72 \mathrm{~h}$ before the pathogen inoculation, followed by four applications at $7 \mathrm{~d}$ intervals, reduced $P$. capsici on pepper by 45 to $64 \%$. This result indicates further research is warranted. The most consistent results in control of Phytophthora crown rot were provided by $F$. solani FUS25 (60-64\%\% efficacy). The same biocontrol strain sometimes provided good, but variable results (8-54\% efficacy) on zucchini, when applied to growing medium immediately at inoculation with $P$. capsici and 5-6 d before planting (Gilardi et al., 2020). Although the mechanism of action of $F$. solani FUS25 is not known, the most likely strategy for its use should be as a protectant or in preventative treatments. Establishment of BCAs in host root systems can also vary according to the host. The root systems of sweet pepper have greater surface areas than root systems of zucchini, which instead develops roots with few branches.

The good results obtained in the present study add evidence for applying BCAs in soilless cultivation systems against diseases caused by oomycetes. Pseudomonas sp. is known to be effective in reducing cucumber root colonization by Pythium aphanidermatum (Moulin et al., 1994; Chatterton et al., 2004), and Pythium disease on cucumber grown in a closed rockwool system (Postma et al., 2000). Streptomyces griseoviride ('Mycostop') is effective against Pythium ultimum on cucumber (Wolfhechel and Funck Jensen, 1991), while Trichoderma virens ('Soilgard') and Gliocladium catenulatum ('Prestop') are active against Pythium aphanidermatum, the causes of the damping-off of cucumbers grown in rockwool (Punja and Yip, 2003).
Increased understanding of BCA modes of action is needed to achieve a widespread application of these agents. Disease suppression could be related to different mechanisms: including production of antibiotics, secondary metabolites, lytic enzymes, phytohormones, siderophores, volatiles, and induction of host resistance (Köhl et al., 2019). For example, pepper plants inoculated with Fusarium oxysporum f. sp. lycopersici developed local and systemic resistance against $P$. capsici (Silvar et al., 2009), and the foliar pathogen Botrytis cinerea (Di'az et al., 2005). Endophytic Trichoderma isolates induced resistance in hot pepper to P. capsici (Bae et al., 2011). Pseudomonas induced motility inhibition of P. capsici zoospores (Zohara et al., 2016), which are the only mobile propagules found in recirculating nutrient solutions (Stanghellini et al., 1996). Iron competition was important in the antagonistic activity of Trichoderma asperellum against $F$. oxysporum $\mathrm{f}$. sp. lycopersici of tomato grown in a soilless medium based on perlite (Segarra et al., 2010).

Little is known about the capability of biocontrol agents to suppress Phytophthora blight on peppers grown in soilless systems.

Selected strains of the Pseudomonas, Bacillus, and Trichoderma have long been known for ability to improve plant growth and induce host systemic resistance against diseases and pests in different ecosystems, including soilless systems (Paulitz, 1997; Domenech et al., 2006; Gravel et al., 2007; Berg, 2009; Lee and Lee, 2015.; Sambo et al., 2019). Several biocontrol agents introduced into hydroponically grown fruit and vegetables have provided positive effects on yields and quality of horticultural products. In the present study, significant reduction in Phytophthora crown rot observed after treatment with Fusarium solani FUS25 was confirmed, by increased biomass fresh weight, with similar or greater increases than those from the commercial mixture of Trichoderma asperellum $+T$. gamsii.

In general, if a biocontrol agent is given time to become well-established in plant growth media, before pathogens are introduced (often through planting material), it can prevent infections or can interfere with pathogen inoculum production that may spread throughout the systems (Fry, 1982). Pseudomonas chlororaphis, Bacillus cereus, and B. gladioli strains, applied in smallscale hydroponic units, suppressed root colonization of chrysanthemum by Pythium aphanidermatum when applied 14-7 d before pathogen inoculation, rather than at the same time as inoculation (Liu et al., 2007). Selected antagonistic Pseudomonas, Fusarium or Trichoderma strains, previously tested in pot trials in peat medium against Fusarium wilt agents of lettuce and wild rocket 
(Gilardi et al., 2019; Srinivasan et al., 2009), or in naturally infested soil in a zucchini-P. capsici pathosystem (Cucu et al., 2020), were here used in preventative treatments in a closed soilless system, before inoculation of peat substrate with $P$. capsici. Optimizing the conditions in the soilless environment to which biocontrol agents were introduced, resulted in improved disease management consistency.

The results obtained in this study provide evidence for using phosphite-based products and biocontrol agents against Phytophthora crown and root rot of pepper, grown in soilless systems. They also show that there is not one solution for the management of these diseases. Different options should be considered and adapted to the different situations, relying on good extension services. Soilless cultivation provides good opportunities for exploitation and practical application of new disease management tools, such as resistance inducers and biocontrol agents. These have been intensively studied in recent years, expanding the integrated disease management options for intensive vegetable production (Paulitz, 1997; Lamichhane et al., 2017; Messelink et al., 2020).

\section{ACKNOWLEDGEMENTS}

This research was funded from Fondazione Cassa Risparmio Cuneo, Agroalimentare 4.0, SFIDA Project 'Low environmental impact management strategies for the horticultural sector'. The authors thank Marguerite Jones for language revision of the paper manuscript, and Dr. Massimo Pugliese and AgriNewTech s.r.l for providing the Pseudomonas sp. PB26, Fusarium solani FUS25 and Trichoderma sp. TW2 microorganisms. The authors thank the anonymous referees and Prof. Richard Falloon for the helpful suggestions and manuscript improvement.

\section{LITERATURE CITED}

Acquadro A., Barchi L., Portis E., Nourdine M., Carli C., ... Lanteri S., 2020. Whole genome resequencing of four Italian sweet pepper landraces provides insights on sequence variation in genes of agronomic value. Scientific Reports 10: 9189.

Bae H., Roberts D. P., Lim H.-S., Strem M. D., Park S.-C., ... Bailey, B. A., 2011. Endophytic Trichoderma isolates from tropical environments delay disease onset and induce resistance against Phytophthora capsici in hot pepper using multiple mechanisms. Molecular Plant Microbe Interactioms 24: 336-351.
Barchenger D.W., Lamour K.H., Bosland P.W., 2018. Challenges and strategies for breeding resistance in Capsicum annuum to the multifarious pathogen, Phytophthora capsici. Frontiers Plant Science 9: 628.

Barratt B.I.P., Moran V.C., Bigler F., van Lenteren J.C., 2018. The status of biological control and recommendations for improving uptake for the future. BioControl 63: 155-167.

Berg G., 2009. Plant-microbe interactions promoting plant growth and health: perspective for controlled use of microorganisms in agriculture. Applied Microbiology and Biotechnology 84: 11-18.

Bi Y., Hu J., Cui X., Shao J., Lu X., ... Liu X., 2014. Sexual reproduction increases the possibility that Phytophthora capsici will develop resistance to dimethomorph in China. Plant Pathology 63: 1365-1373.

Bower L. A., Coffey M.D., 1985. Development of laboratory tolerance to phosphorous acid, fosetyl-Al, and metalaxyl in Phytophthora capsici. Canadian Journal of Plant Pathology 7:1-6.

Calvo-Bado L. A., Petch G. M., Parsons N., Morgan J. A. W., Pettitt T. R., Whipps J. M., 2006. Microbial community responses associated with the development of oomycete plant pathogens on tomato roots in soilless growing systems. Journal of Applied Microbiology 100: 1194-1207.

Chatterton S., Sutton J., Boland G., 2004. Timing Pseudomonas chlororaphis applications to control Pythium aphanidermatum, Pythium dissotocum, and root rot in hydroponic peppers. Biological Control 30: 360373.

Cherif M., Asselin A. Belanger R. R., 1994. Defense responses induced by soluble silicon in cucumber roots infected by Pythium spp. Phytopathology 84: 236-242.

Clematis F., Minuto A., Gullino M.L., Garibaldi A. 2009. Suppressiveness to Fusarium oxysporum f. sp. radicislycopersici in re-used perlite and perlite-peat substrates in soilless tomatoes. Biological Control 48: 108-114.

Cucu M. A., Gilardi G., Pugliese M., Ferrocino I., Gullino M. L., 2020. Effects of biocontrol agents and compost against the Phytophthora capsici of zucchini and their impact on the rhizosphere microbiota. Applied Soil Ecology 154: 103659.

Dı'az J., Silvar C., Varela M.M., Bernal A., Merino F., 2005. Fusarium confers protection against several pathogenic fungi in pepper. Plant Pathology 54: 773780 .

Dobrowolski M. P., Shearer B. L., Colquhoun I. J., O'Brien P. A., Hardy G. E. S. J., 2008. Selection for decreased sensitivity to phosphite in Phytophthora 
cinnamomi with prolonged use of fungicide. Plant Pathology 57: 928-936.

Domenech J., Reddy M.S., Kloepper J.W., Ramos B., Gutierrez-Mañero J., 2006. Combined application of the biological product LS213 with Bacillus, Pseudomonas or Chryseobacterium for growth promotion and biological control of soil-borne diseases in pepper and tomato. Biocontrol 51: 245-258.

Fagundes-Nacarath I.R.F., Debona D., Brás V.V., Silveira P.R., Rodrigues F.A., 2018. Phosphites attenuate Sclerotinia sclerotiorum-induced physiological impairments in common bean. Acta Physiologiae Plantarum 40: 198.

FAOSTAT 2019. Crop Production Data. Rome: Food and Agriculture Organization of the United Nations. Available at http://www.fao.org/faostat/en/\#data. Accessed March 13, 2019.

Fenn M.E., Coffey M.D., 1984. Studies on the in vitro and in vivo antifungal activity of fosetyl-Al and phosphorous acid. Phytopathology 74: 606- 611.

Förster H., Adaskaveg J. E., Kim D. H., Stanghellini M. E., 1998. Effect of phosphite on tomato and pepper plants and on susceptibility of pepper to Phytophthora root and crown rot in hydroponic culture. Plant Disease 82: 1165-1170.

Foster J.M., Hausbeck M.K., 2010. Resistance of pepper to Phytophthora crown, root, and fruit rot is affected by isolate virulence. Plant Disease 94: 24-30.

French-Monar R., Rodrigues F. A., Korndöfer G. H., Datnoff L. E., 2010. Silicon suppresses Phytophthora blight development on bell pepper. Journal of Phytopathology 158: 554-560.

Fry W.E., 1982. Principles of Plant Disease Management. Academic Press, New York, USA, 378 pp.

Garibaldi A., Gilardi G., Gullino M.L., 2014. Critical aspects in disease management as a consequence of the evolutionof soil-borne pathogens. Acta Horticolturae 1044: 43-52.

Gevens A. J., Donahoo R. S., Lamour K. H., Hausbeck M. K., 2007. Characterization of Phytophthora capsici from Michigan surface irrigation water. Phytopathology 97: 421-428.

Gilardi G., Demarchi S., Martano G., Gullino M.L., Garibaldi A., 2014. Success and failures of grafting pepper against soil-borne pathogens. Acta Horticulturae 1044: 67-71.

Gilardi G., Demarchi S., Gullino M.L., Garibaldi A., 2015. Nursery treatments with non-conventional products against crown and root rot, caused by Phytophthora capsici, on zucchini. Phytoparasitica 43: 501-508.

Gilardi G., Demarchi S., Gullino M.L., Garibaldi A., 2016. Evaluation of the short term effect of nursery treat- ments with phosphite-based products, acibenzolarS-methyl, pelleted Brassica carinata and biocontrol agents, against lettuce and cultivated rocket fusarium wilt under artificial inoculation and greenhouse conditions. Crop Protection 85: 23-32.

Gilardi G., Pugliese M., Gullino M.L., Garibaldi A., 2019. Nursery treatments with resistant inducers, soil amendments and biocontrol agents for the management of the Fusarium wilt of lettuce under glasshouse and field conditions. Journal of Phytopathology 167: 98-110.

Gilardi G., Pugliese M., Gullino M.L., Garibaldi A., 2020. Effect of biocontrol agents and potassium phosphite against Phytophthora crown rot, caused by Phytophthora capsici, on zucchini in a closed soilless system. Scientia Horticolturae 265: 109207.

Gomez-Merino F.C. and Trejo-Téllez L.I.T., 2015. Biostimulant activity of phosphite in horticulture. Scientia Horticolturae 196: 82-90.

Granke L. L., Quesada-Ocampo L., Lamour K., Hausbeck M. K., 2012. Advances in research on Phytophthora capsici on vegetable crops in the United States. Plant Disease 96: 1588-1600.

Gravel V., Antoun H., Tweddell R.J., 2007. Growth stimulation and fruit yield improvement of greenhouse tomato plants by inoculation with Pseudomonas putida or Trichoderma atroviride: possible role of indole acetic acid (IAA). Soil Biology and Biochemistry 39: 1968-1977.

Guest D.I., Bompeix G., 1990. The complex mode of action of phosphonates. Australasian Plant Pathology 19: 113-115.

Gullino M.L., Pugliese M., 2011. New strain of Fusarium solani and its uses. Patent number IT2011TO01016.

Grant B.R., Dunstan R.H., Griffith J.M., Niere J.O., Smillie R.H., 1990. The mechanism of phosphonic (phosphorous) acid action in Phytophthora. Australasian Plant Pathology 19: 115-121.

Hausbeck M.K., Lamour K. H., 2004. Phytophthora capsi$c i$ on vegetable crops: research progress and management challengers. Plant Disease 88: 1292-1303.

Hong C.X., Moorman G.W., 2005. Plant pathogens in irrigation water: challenges and opportunities. Critical Reviews in Plant Sciences 24: 189-208.

Hunter S., Williams N., McDougal R., Scott P., Garbelotto M., 2018. Evidence for rapid adaptive evolution of tolerance to chemical treatments in Phytophthora species and its practical implications. PLOS ONE 13(12): e0208961.

Hwang B.K., Kim Y.J., Kim C.H., 1996. Differential interactions of Phytophthora capsici isolates with pepper genotypes at various growth stages. European Journal of Plant Pathology 102: 311-316. 
Jayawardana H., Weerahewa, H.L.D., Saparamadu M., 2015. Enhanced resistance to anthracnose disease in chili pepper (Capsicum annuum L.) by amendment of the nutrient solution with silicon. The Journal of Horticultural Science and Biotechnology 90: 557-562.

Jenkins S.F., Averre C.W., 1983. Root diseases of vegetables in hydroponic culture systems. Plant Disease 67: 968-970.

Khalil S., Alsanius, W.B., Hultberg M., 2009. Effect of growing media on the interaction between biocontrol agents and root pathogens in a closed hydroponic system. Journal of Horticultural Science and Biotechnology 84: 489-494.

Khalil S., Alsanius W.B., 2011. Effect of growing medium water content on the biological control of root pathogens in a closed soilless system. Journal of Horticultural Science and Biotechnology 86: 298-304.

Kim K. D., Nemec S., Musson G. 1997. Effects of composts and soil amendments on soil microflora

and Phytophthora root and crown rot of bell pepper. Crop Protection 16: 165-172.

Köhl J., Kolnaar R., Ravensberg W.J., 2019. Mode of action of microbial biological control agents against plant diseases: relevance beyond efficacy. Frontiers Plant Science 10: 845.

Köhl J., Postma J., Nicot P., Ruocco M., Blum B., 2011. Stepwise screening of microorganisms for commercial use in biological control of plant-pathogenic fungi and bacteria. Biological Control 57: 1-12.

Kousik C. S., Keinath A. P., 2008. First report of insensitivity to cyazofamid among isolates of Phytophthora capsici from the southeastern United States. Plant Disease 92: 979.

Lamichhane J.R., Bischoff-Schaefer M., Bluemel S., Dachbrodt-Saaydeh S., Dreux L. K., ... Villeneuve F., 2017. Identifying obstacles and ranking common biological control research priorities for Europe to manage most economically important pests in arable, vegetable and perennial crops. Pest Management Science 73: 14-21.

Lamour K. H., Hausbeck M. K., 2001. The dynamics of mefenoxam insensitivity in a recombining population of Phytophthora capsici characterized with amplified fragment length polymorphism markers. Phytopathology 91: 533-557.

Lee B.K., Kim B.S., Chang S.W., Hwang B. K., 2001. Aggressiveness to pumpkin cultivars of isolates of Phytophthora capsici from pumpkin and pepper. Plant Disease 85: 497-500.

Lee S., Lee J., 2015. Beneficial bacteria and fungi in hydroponic systems: types and characteristics of hydroponic food production methods. Scientia Horticolturae 195: 206-215.

Liang Y., Hua H., Zhu Y., Zhang J., Cheng C., Romheld V. 2006. Importance of plant species and external silicon concentration to active silicon uptake and transport. New Phytology 172: 63-72.

Liu P., Li B., Lin M., Chen G., Ding X., Weng Q., 2016. Phosphite induced reactive oxygen species production and ethylene and ABA biosynthesis mediate the control of Phytophthora capsici in pepper (Capsicum annuum). Functional Plant Biology 43: 563-574.

Liu W., Sutton J.C., Grodzinski B., Kloepper J., 2007. Biological control of Pythium root rot of chrysanthemum in small-scale hydroponic units. Phytoparasitica 35: $159-178$.

Lobato M.C., Olivieri F.P., Daleo G.R., Andreu A.B., 2010. Antimicrobial activity of phosphites against different potato pathogens. Journal Plant Disease Protection 117: 102-109.

Masago H., Yoshikawa M., Fukada M., Nakanishi N., 1977. Selective inhibition of Pythium spp. On a medium for direct isolation of Phytophthora spp. From soils and plants. Phytopathology 67: 425-428.

Matta A., Garibaldi A., 1981. Malattie delle piante ortensi, Edagricole Bologna, Italy, 232 pp.

Mercier J., Manker D.C., 2005. Biocontrol of soil-borne diseases and plant growth enhancement in greenhouse soilless mix by the volatile producing fungus Muscodor albus. Crop Protection 24: 355-362.

Messelink G.J., Labbé R., Marchand G., Tavella L., 2020. Sweet pepper: Main Pest and Diseases Problems. In: Integrated Pest and Disease Management in Greenhouse Crops (M.L. Gullino, R. Albajes, P. Nicot, J.C. Van Lenteren, eds.), Springer, Dordrecht, The Netherlands, 513-535.

Miao J., Cai M., Dong X., Liu L., Lin D., ... Liu, Xiii, 2016. Resistance assessment for oxathiapoprolin in Phytophthora capsici and the detection of a point mutation (G769W) in PcORP1 that confers resistance. Frontiers in Microbiology 7: 615.

Moulin F., Lemaceau P., Alabouvette C., 1994. Pathogenicity of Pythium species on cucumbers in peatsand, rockwool and hydroponics. European Journal of Plant Pathology 100: 3- 17.

Nielsen C.J., Ferrin D.M., Stanghellini M.E., 2006a. Efficacy of biosurfactants in the management of Phytophthora capsici on pepper in recirculating hydroponic systems. Canadian Journal of Plant Pathology 28: 450-460.

Nielsen C.J., Ferrin D.M., Stanghellini M.E., 2006b. Cyclic production of sporangia and zoospores by Phytophthora capsici on pepper roots in hydroponic culture. Canadian Journal of Plant Pathology 28: 461-466. 
Owen-Going T.N., Sutton J.C., Grodzinski B., 2003. Relationships of Pythium isolates and pepper plants in single-plant hydroponic units. Canadian Journal of Plant Pathology 25: 155-167.

Parra G., Ristaino J.B., 2001. Resistance to mefenoxam and metalaxyl among field isolates of Phytophthora capsici causing Phytophthora blight of bell pepper. Plant Disease 85: 1069-1075.

Paulitz T.C., 1997. Biological control of root pathogens in soilless and hydroponic systems. Horticultural Science 32: 193-196.

Punja Z.K., Yip R., 2003. Biological control of dampingoff and root rot caused by Pythium aphanidermatum on greenhouse cucumbers. Canadian Journal of Plant Pathology 25: 411-417.

Pernezny K. L., Roberts P. D., Murphy J. F., Goldberg N. P., 2003. Compendium of Pepper Diseases. 1th ed.American Phytopathological Society Press, St Paul, USA, $63 \mathrm{pp}$.

Postma J., Willemsen-de Klein M.J.E.I.M., Van Elsas J.D., 2000. Effect of the indigenous microflora on the development of root and crown rot caused by Pythium aphanidermatum in cucumber grown on rockwool. Phytopathology 90: 125-133.

Postma J. 2009. The Status of Biological Control of Plant Diseases in Soilless Cultivation. In: Recent Developments in Management of Plant Diseases (U. Gisi, I. Chet, M.L. Gullino, eds.) Springer, Dordrecht, The Netherlands, 133-146.

Pugliese M., Liu B.P., Gullino M.L., Garibaldi A., 2008. Selection of antagonists from compost to control soil-borne pathogens. Journal of Plant Disease and Protection 115: 220-228.

Rankin L., Paulitz T.C., 1994. Evaluation of rhizosphere bacteria for biological control of Pythium root rot of greenhouse cucumbers in hydroponic culture. Plant Disease 78: 447-451.

Raymaekers K., Ponet L., Holtappels D., Berckmans B., Cammue P.A.B., 2020. Screening for novel biocontrol agents applicable in plant disease management - a review. Biological Control 144: 104240.

Ristaino J.B., Johnston S.A., 1999. Ecologically based approached to management of Phytophthora blight on bell pepper. Plant Disease 83: 1080-1089.

Ristaino J. B., Larkin R. P., Campbell C. L., 1993. Spatial and temporal dynamics of Phytophthora epidemics in commercial bell pepper fields. Phytopathology 83: 1312-1320.

Sambo P., Nicoletto C., Giro A., Pii Y., Valentinuzzi F.,... Cesco S., 2019. Hydroponic Solutions for Soilless Production Systems: Issues and Opportunities in a Smart Agriculture Perspective. Frontiers in Plant Science 10: 923.
Segarra G., Casanova E., Avilés M., Trillas I., 2010. Trichoderma asperellum strain T34 controls Fusarium wilt disease in tomato plants in soilless culture through competition for iron. Microbial Ecology 59: 141-149.

Shaner G., Finney R.E., 1977. The effect of nitrogen fertilization on the expression of slow-mildewing resistance in Knox wheat. Phytopathology 67: 1051-1056.

Shearer B.L., Crane C.E., 2012. Variation within the genus Lambertia in efficacy of low-volume aerial phosphite spray for control of Phytophthora cinnamomi. Australasian Plant Pathology 4: 147-57.

Sibilia C., 1952. Review of the most important phytopathological records observed in 1949 on Capsicum annuum, Italy. Stazione di Patologia Vegetale Bollettino, Roma, Sor III, 8, 285.

Silvar C., Merino F., D1' az J., 2009. Resistance in pepper plants induced by Fusarium oxysporum f. sp. lycopersici involve different defence-related genes. Plant Biology 11: 68-74.

Smillie R., Grant B.R., Guest D., 1989. The mode of action of phosphite: evidence of both direct and indirect modes of action on three Phytophthora spp. in plants. Phytopathology 79: 921-926.

Song A., Xue G., Cui P., Fan F., Liu H., ... Liang Y., 2016. The role of silicon in enhancing resistance to bacterial blight of hydroponic-and soil-cultured rice Scientific Reports 6: 24640.

Srinivasan K., Gilardi G., Garibaldi A., Gullino M.L., 2009. Bacterial antagonists from used rockwool soilless substrates suppress Fusarium wilt of tomato. Journal of Plant Pathology 91: 147-154.

Stanghellini M.E. Tomlinson A. 1987. Inhibitory and lytic effects of nonionic surfactant on various asexual stages in the life cycle of Pythium and Phytophthora species. Phytopathology 77: 112-114.

Stanghellini M.E., Miller R.M., 1997. Biosurfactants: their identity and potential efficacy in the biological control of zoosporic plant pathogens. Plant Disease 81: 4-12.

Stanghellini M.E., Kim D.H., Rasmussen S.L., Rorabaugh P.A., 1996. Control of root rot of peppers caused by Phytophthora capsici with a non-ionic surfactant. Plant Disease 80: 1113-1116.

Stanghellini M.E., Rasmussen S., 1994. Hydroponics: a solution for zoosporic pathogens. Plant Disease 74: 173-178.

Tamietti G., Valentino D., 2001. Physiological characterization of a population of Phytophthora capsici Leon. from northern Italy. Journal of Plant Pathology 83: 199-205.

Vallance D., Guérin-Dubrana F., Blancard D., Rey P., 2011. Pathogenic and beneficial microorganisms in 
soilless cultures. Agronomy for Sustainable Development 31: 191-203.

Van Der Gaag D. J., Wever G., 2005. Conduciveness of different soilless growing media to Pythium root and crown rot of cucumber under near-commercial conditions. European Journal of Plant Pathology 112: 31-41.

Wang M., Gao L., Dong S., Sun Y., Shen Q., Guo S., 2017. Role of Silicon on Plant-Pathogen Interactions. Annunci Frontiers in Plant Science 8: 701.

Wolfhechel H., Funck Jensen D., 1991. Influence of the water potential of peat on the ability of Trichoderma harzianum and Gliocladium virens to control Pythium ultimum. In: Biotic interactions and soil-borne diseases (A.B.R. Beemster, G.J. Bollen, M. Gerlagh, M.A. Ruissen, B. Schippers, A. Tempel ed.), Elsevier, Amsterdam, The Netherlands, 392-397.

Zheng J., Sutton J.C., Yu H., 2000. Interactions among Pythium aphanidermatum, roots, root mucilage, and microbial agents in hydroponic cucumbers. Canadian Journal of Plant Pathology 22: 368-379. 